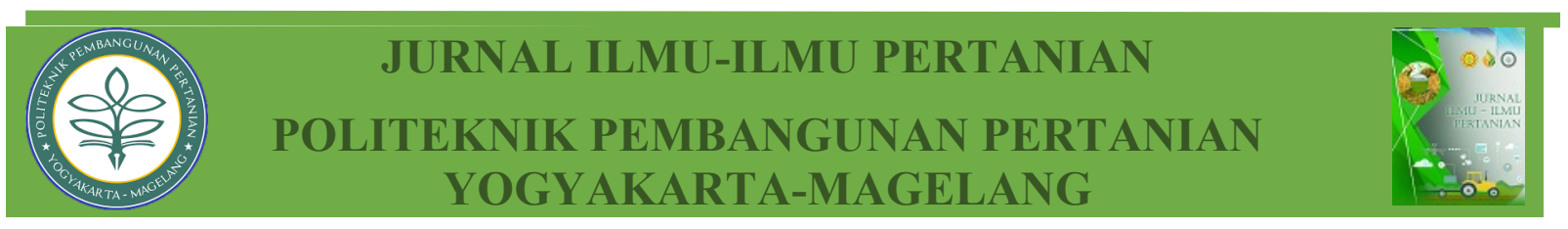

\title{
PENUMBUHAN ANIMO PENGGUNAAN PUPUK ORGANIK CAIR UNTUK BIOREMEDIASI LAHAN DAN PENINGKATAN PRODUKSI PADI MELALUI PENDEKATAN KEY PERSON
}

\author{
Fransiskus Xaverius Hery Priyono ${ }^{1}$ \\ ${ }^{1}$ Dinas Pertanian Ketahanan Pangan Kabupaten Brebes, Provinsi Jawa Tengah
}

Received
Accepted
Published
Copyright
: July $16^{\text {th }}, 2021$

: October $6^{\text {th }}, 2021$

: November $17^{\text {th }}, 2021$

: Authors retain copyright and grant the journal right of first publication with This work is licensed under a Creative Commons Attribution-Non Commercial 4.0 International License.

ABSTRAK: Penggunaan pestisida kurang bijaksana semakin meluas dapat menurunkan kualitas lahan, secara fisis, khemis, biologis, rusaknya ekosistem, rantai makanan, punahnya biota tanah dan perlunya perbaikan. Penelitian ini dilakukan di BPP Larangan Brebes pada Februari 2020 dengan metode pengambilan sampel acak berjenjang. Penelitian ini bertujuan mengetahui Pendekatan Key Person untuk menumbuhkan animo penggunaan pupuk organik cair untuk bioremediasi lahan dan peningkatan produksi padi. Data diolah menggunakan Excel. Hasil penelitian menunjukkan jumlah anakan memiliki kontrol rerata 14,07, POC dengan rerata 27,73. Berat malai: Kontrol rerata 3,68 gr, POC rerata 4,15 gr. Panjang malai: Kontrol rerata 24,50 cm POC rerata 26,11 cm. Jumlah bulir: Kontrol rerata 144,27 POC rerata 153,17. Berat seribu butir: Kontrol rerata 26,20 gr, POC rerata 27,12 gr. Bioremediasi lahan dari kenampakan fisik dan pengukuran dengan alat sederhana, uji Kapasitas Tukar Kation. Kontrol lampu redup, POC Nyala Terang. Hasil soil test kit kontrol miskin NPK, POC Hara Makro NPK sangat subur, pengukuran pH: kontrol asam, POC Normal. Kontribusi kenaikan produksi padi: Jumlah Anakan meningkat 97,09\%(SN) terhadap kontrol. Berat Malai meningkat 12,77\%(N) terhadap kontrol; Panjang Malai meningkat 6,53\%(N) terhadap kontrol. Jumlah Bulir Permalai meningkat 6,17\%(N) terhadap control. Bobot Seribu Butir meningkat 3,51\%(N) terhadap kontrol, Jumlah Cabang Malai meningkat $(-3,55 \%)$ (TN) terhadap kontrol. Melalui pendekatan Key Person dan animo Penggunaan POC meningkatkan kesuburan lahan dan berdampak pada peningkatan produksi Padi

Kata kunci: animo, Brebes, bioremediasi, Key Person, lahan, padi, POC. 
ABSTRACT: The use of pesticides is less ineffective and can increasingly reduce the quality of land, physically, chemically, biologically, damage to ecosystems, food chains, and the need for improvement. The study was done in BPP Larangan Brebes in February 2020; Random sampling method. This research aimed to determine the Key Person Approach to grow the interest in using liquid organic fertilizer for land bioremediation and increasing rice production. Data were processed using excel whereas Tillers Control means 14.07, POC mean 27.73. Panicle weight: Control average 3.68gr, average POC 4.15gr. Panicle length: control mean $24.50 \mathrm{~cm}$, POC mean $26.11 \mathrm{~cm}$. Grains: control means 144.27, POC means 153.17. Weight of a thousand grains: Control average $26.20 \mathrm{gr}$, mean POC $27.12 \mathrm{gr}$. Bioremediation of land from physical appearance and measurement with a tool, the Cation Exchange Capacity test. Dim light control, POC on Bright. Results of Soil Test Kit: Poor control of NPK, POC of NPK Macronutrients very fertile, pH measurement: Acid Control, Normal POC. The contribution of the increase in rice production: the number of tillers increased $97.09 \%$ (VS) to the control. Panicle weight increased $12.77 \%$ (S) to the control; Panicle length increased $6.53 \%$ (S) control. The grain is increased by $6.17 \%$ (S) to the control. The weight of a thousand items increased by 3.51\% (S) for the control, Panicle branches increased (-3.55\%) (NS) for the control. In conclusion, the Key Person approach and the interest of using POC to increase land fertility and impact rice production.

Keywords: bioremediation, Brebes, interest, Key Person, land, POC, rice.

\section{PENDAHULUAN}

Kabupaten Brebes yang berada di jalur pantura provinsi Jawa Tengah dengan berbatasan langsung disebelah utara dengan Laut Jawa sebelah timur dengan Kotamadya Tegal Kabupaten Tegal, sebelah selatan dengan Kabupaten Banyumas dan Kabupaten Cilacap serta batas bagian barat dengan Kabupaten Ciamis Kabupaten Kuningan dan Kabupeten Cirebon Povinsi Jawa Barat. Potensi penghasil pangan padi jagung dan kedelai tersebar di 17 kecamatan di kabupaten brebes mulai dari produksi beras putih kepala super, beras putih premuim, beras putih biasa, beras ketan putih, beras ketan hitam, beras hitam super, jagung, kedelai ,ketela, ubi jalar, kacang tanah, pisang dll.

Luas Daerah Kabupaten Brebes, menurut Anonim (2015), seluas166.296 Hektar dengan perincian luas lahan sawah sebesar 62.703 Hektar; Luas pekarangan/bangunan 19.250 Hektar; Luas Lahan Tegalan/ Kebonan 17.499 Hektar;
Tambak Rawa kolam empang 9.001 Hektar; Hutan Rakyat 5.557 Hektar; Hutan Negara 46.708 Hektar; Perkebunn negara/swasta 1.252 Hektar; Tanah yang sementara tidak digunakan 279 Hektar; dan Lain Lain seluas 4.047 Hektar.

Luas total sawah 62.703 Hektar dan lahan bukan sawah seluas 103,593 Hektar dengan perincian tanah sawah berpengairan tekhnis seluas 26,553 Hektar; sawah dengan pengairan setengah teknis 10.697 Hektar; sawah dengan pengairan sederhana 8.837 Hektar dan sawah dengan pengairan tadah hujan 16.616 Hektar.

Di Kabupaten Brebes, menurut Anonim (2017), terdapat 2 (dua) waduk besar yang mampu mensuplai kebutuhan air baku pertanian yakni Waduk Malahayu (dengan luas \pm 925 Hektar) berada di Kecamatan Banjarharjo wilayah Brebes Barat dan Waduk Penjalin ( dengan luas \pm 125 Hektar) berada di Kecamatan Paguyangan wilayah Brebes selatan serta Bendung Notog yang berada di wilayah Kabupaten Tegal tetapi dibuat untuk 
mengairi wilayah Kabupaten Brebes, kedua Waduk dan Bendung tersebut dibangunan sejak zaman Pemerintahan Penjajahan Belanda.

Potensi Sumber Daya Manusia, Jumlah Penduduk di Kabupaten Brebes sebesar 1.748.510 jiwa dengan perbandingan penduduk laki - laki 879.460 jiwa dan penduduk perempuan 869.050 jiwa, dengan seks rasio 101,20, Anonim (2017).

Penduduk yang mempunyai mata pencaharian petani/peternak sebesar 312.825 jiwa; Buruh tani 387.502 jiwa dan penduduk dengan mata pencaharian Nelayan sebanyak 27.233 jiwa.

Ada beberapa penyebab yang dapat dijumpai di lapangan menurut Anonim (2019), antara lain: Pola usaha tani, Tingkat penerapan teknologi, Tingkat kesuburan dan pola tanam. Penggunaan Pupuk yang belum tepat, Kurang optimalnya penggunaan Tekhnologi Informatika (IT) untuk menggali/berbagai informasi pertanian, Varietas Tanaman, Organisme Pengganggu Tanaman (OPT) seperti: Hama penggerek sundep beluk blas dengan intensitas yang variatif dampak dari anomali kemarau basah yang terjadi, pemilihan lokasi demplot percontohan, pengambilan sampel dalam pelaksanaan ubinan, koordinasi antar instansi serta padatnya intensitas aktivitas pekerjaan di lapangan.

Hal murah yang belum dilaksanakan menurut Anonim (2018), tetapi sebenarnya dapat menjadi impact point dalam penyuluhan pertanian (Savil dalam Moersantoro, 1988), diantaranya penggunaan POC/Pupuk Organik Cair yang berfungsi sebagai bioremediasi lahan/pengembalian kesuburan karena rusaknya lahan pertanian di brebes akibat pestisida, (Faiz, 2016) melalui pendekatan personal kepada Tokoh.

Berdasarkan hasil analisa agroekosistem dan survey melalui wawancara kepada responden yang dilakukan pada tanggal 20-24 Februari
2020 di lokasi Desa Luwunggede Kecamatan Larangan Kabupaten Brebes diketahui animo responden terhadap bioremediasi dan upaya peningkatan produksi padi dengan pengunaan POC / Pupuk Organik Cair.

Tujuan penelitian ini untuk mengetahui animo Penggunaan POC terhadap bioremediasi dan upaya peningkatan produksi padi pada suatu studi Kasus Penyuluhan di Desa XX Kecamatan YY Kabupaten AA, Provinsi Jawa Tengah.

Hasil penelitian ini mungkin berguna untuk menambah pengetahuan dan pengalaman penulis selaku penyuluh pertanian, serta sebagai sumbang saran dan pemikiran kepada pihak pengambil kebijakan, terutama bagi dinas/instansi terkait di pemerintah daerah Kabupaten Brebes dalam rangka ikut mengembalikan tingkat kesuburan lahan pertanian dan mengangkat derajad nilai tambah komoditas unggulan lokal khususnya Beras serta untuk meningkatkatkan pendapatan dan kesejahteraan pelaku utama dan pelaku usaha khususnya para Petani Penanam maupun Pedagang atau Pengusaha Beras di Kabupaten Brebes pada umumnya.

\section{METODE}

Penelitian ini terbatas hanya untuk mengetahui Pendekatan Key Person menumbuhkan animo petani (Werimon. 1994) pada penggunaan POC/Pupuk Organik Cair untuk bioremidiasi lahan dan peningkatan produksi padi di Wilayah Balai Penyuluhan Pertanian BPP Larangan tepatnya desa Luwunggede di Kecamatan Larangan, Kabupaten Brebes Provinsi Jawa Tengah.

Karakteristik populasi yang dimaksud penulis dalam penelitian ini adalah tokoh kunci atau pemuka masyarakat, tokoh petani, baik formal maupun informal, baik yang mengusahakan usaha tani padi, palawija, hortikultura maupun sayuran lainnya. 
Metode penarikan sampel adalah metode penarikan sampel secara random bertahap, langkahnya pertama menentukan pilihan diantara 12 tokoh yang ada dan telah mengaplikasikan POC; Tahapan berikutnya memilih lokasi kecamatan yang ada di kabupaten brebes dari 17 kecamatan diambil satu kecamatan; Kecamatan Larangan, kemudian memilih desa lokasi penelitian; Tahapan berikutnya menentukan Key Persoon/ tokoh kunci (Hariadi Sunarru Samsi, 1994) yang akan di teliti; selanjutnya diadakan observasi dan pengamatan serta pengumpulan data dari lahan tokoh terpilih dalam sample yang menanam padi tersebut, kemudian diambil 60 sampel rumpun tanaman untuk diolah datanya terdiri dari 30 sampel perlakuan control dan 30 sampel perlakuan penggunaan POC.

Cara pengumpulan datanya diperoleh bersama Para Penyuluh Pertanian saat penen padi, dilakukan observasi ke lokasi sawah tokoh kunci, (Projosoeharjo. 1987), kemudian di tentukan lokasi sampel kontrol dan lokasi perlakuan penggunaan POC; Adapun sampel yang di ambil diantaranya menghitung jumlah anakan pada rumpun padi baik perlakuan kontrol maupun perlakuan penggunaan POC penghitungan dengan cara pengamatan dibantu menggunanan alat kounter manual merek "Kenko". Mengambail malai padi untuk selanjutnya ditimbang menggunakan timbangan digital merek "Pocketscale" dengan ketelitian hingga 0.01 Gram dan dicatat hasilnya, baik dari perlakuan kontrol maupun perlakuan penggunaan POC. Selanjutnya malai di ukur panjangnya mulai dari ujung hingga cabang malai paling bawah menggunanakn mistar metal merek "Carinex". Dilanjutkan dengan menghitung jumlah cabang dalam tiap malai baik perlakuan kontrol maupun perlakuan penggunaan POC hasilnya dicatat. Berikutnya pengambilan data jumlah bulir padi permalai caranya menghitung jumlah bulir total dalam setiap malai secara manual dibantu menggunanan alat counter manual merek "Kenko". Kemudian bulir dalam malai di rontokkan dan di pilih yang bernas baik yang perlakuan kontrol maupun perlakuaan penggunana POC kemudian dihitung sebanyak 1000 butir selanjutnya dari masing-masing perlakuan butir gabah yang bernas ditimbang menggunakan timbangan digital merek "Pocketscale" dan dicatat.

\section{HASIL DAN PEMBAHASAN}

\section{Analisis data}

Data yang diperoleh dari lapangan perhitungan mulai dari data jumlah anakan; data berat malai; data panjang malai; data jumlah cabang malai; data jumlah bulir per malai; serta data berat seribu butir gabah padi; semua data di masukkan tabel menggunakan Excel dan dibuat Tabulasi dan Grafik

\section{A. Jumlah Anakan Per Rumpun}

Jumlah anakan kontrol terendah adalah 8 anakan per rumpun dan tertinggi 19 anakan per rumpun dengan rerata 14,067 anakan per rumpun. Sedangkan jumlah anakan perlakukan penggunaan POC denngan data sebagai berikut anakan terendah 20 anak per rumpun dan anakan tertinggi mencapai 33 anakan per rumpun dengan rerata 27,733 anak per rumpun. anakan tertinggi mencapai 33 anakan per rumpun dengan rerata 27,733 anak per rumpun. 


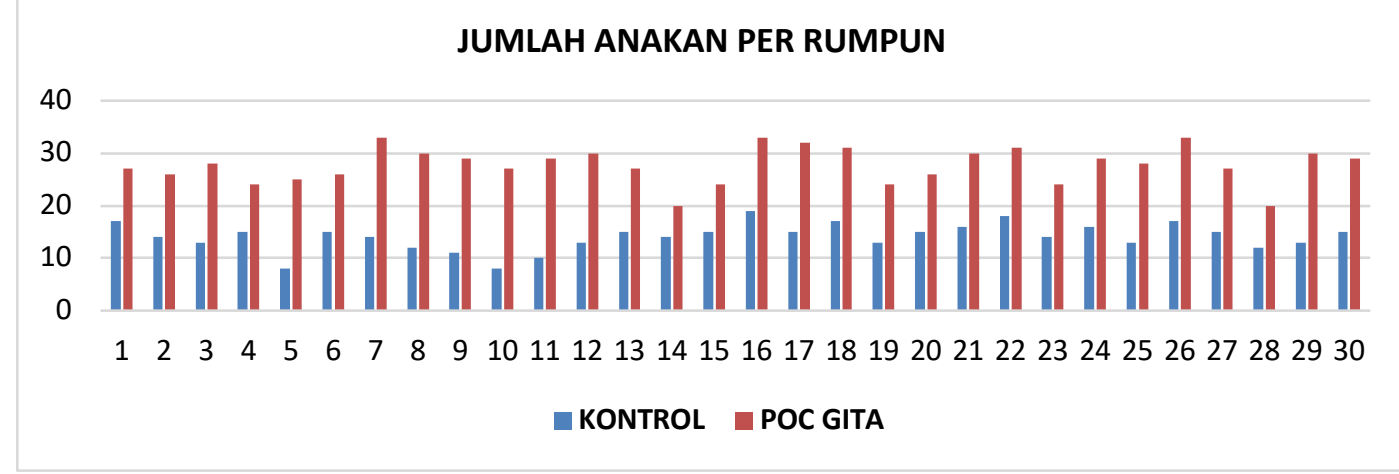

Tabel 1. Tabel Jumlah Anakan Per Rumpun padi, Luwunggede Larangan Brebes 2020

\section{B. Berat malai}

Berat malai kontrol terendah adalah 2,31gram dan tertinggi 5,10 gram dengan rerata 3,68 gram. Sedangkan berat malai penggunaan POC dengan data sebagai berikut Berat malai terendah 2,34 gram dan berat maalai tertinggi mencapai 5,84 gram dengan rerata 4,146 gram.

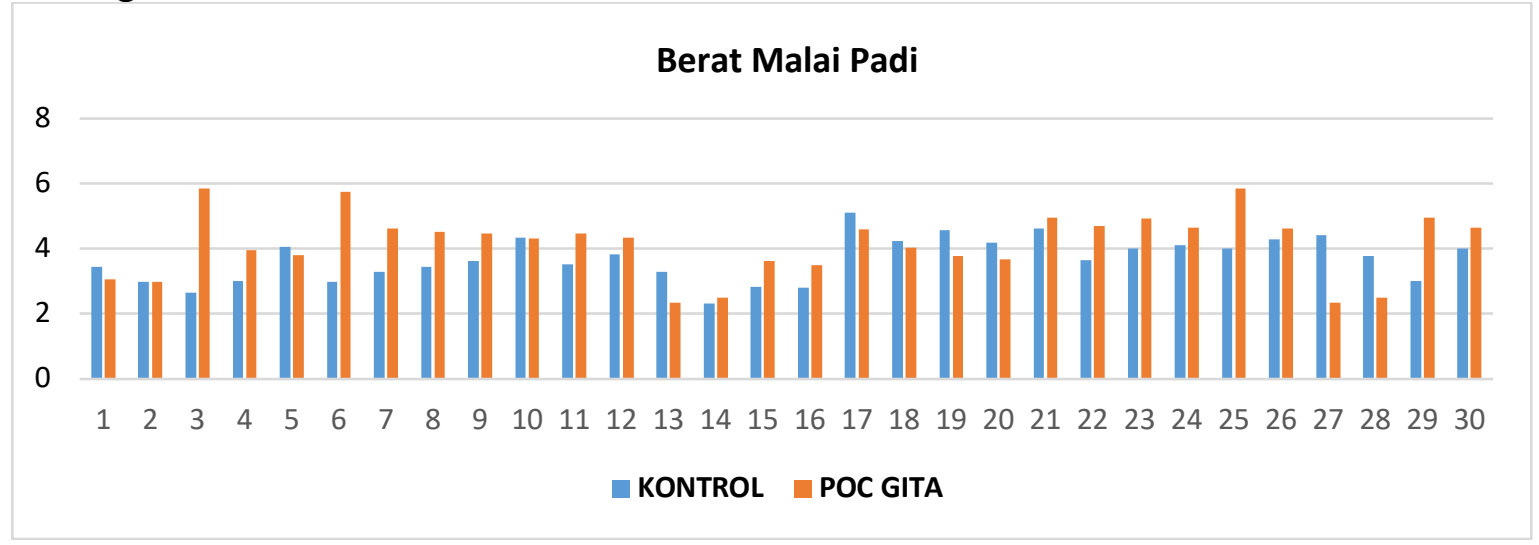

Tabel 2. Tabel Berat malai padi, Luwunggede Larangan Brebes 2020

\section{Panjang malai}

Panjang malai perlalukan kontrol terendah $20,50 \mathrm{~cm}$ dan tertinggi $27,40 \mathrm{~cm}$ dengan rerata $24,51 \mathrm{~cm}$ sedangkan perlalukuan penggunaan POC dengan data sebagai berikut: panjang malai terendah $23,80 \mathrm{~cm}$ dan panjang malai terttinggi $28,10 \mathrm{~cm}$ dengan rerata $26,11 \mathrm{~cm}$.

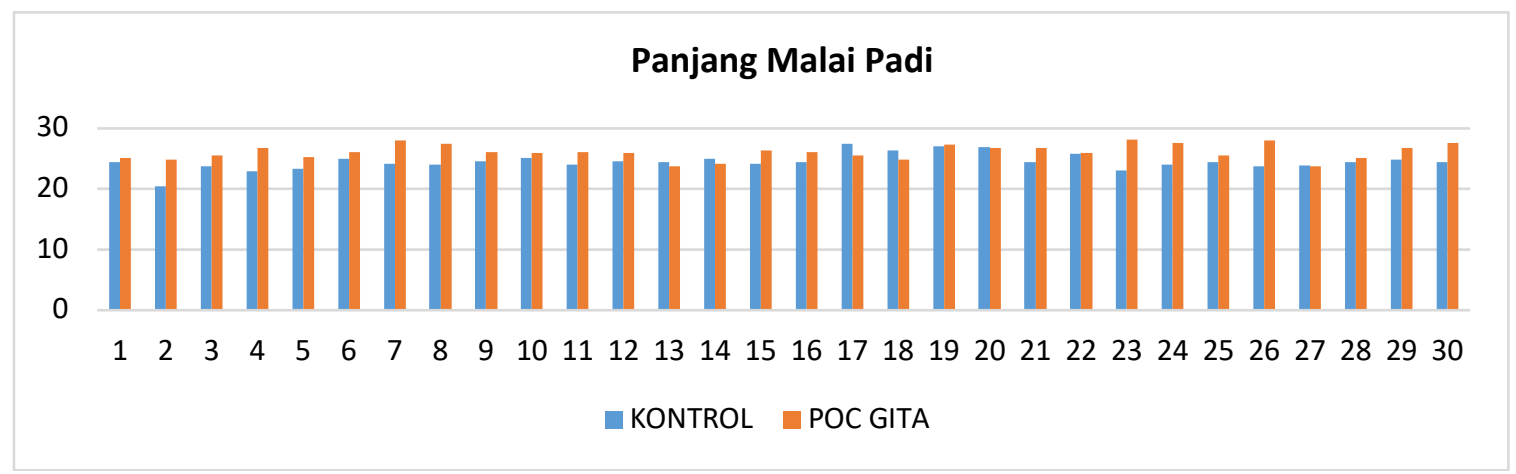

Tabel 3. Tabel Panjang malai padi, Luwunggede Larangan Brebes 2020 
D. Jumlah Cabang Malai

Jumlah cabang malai perkaluan kontrol terendah 10 dan terttinggi 15 dengan rerata 12,133 sedangkan perlakuan penggunaan POC dengan tampilan data sebagai berikut terendah 9 tertinggi 14 dengan rerata 11,70 .

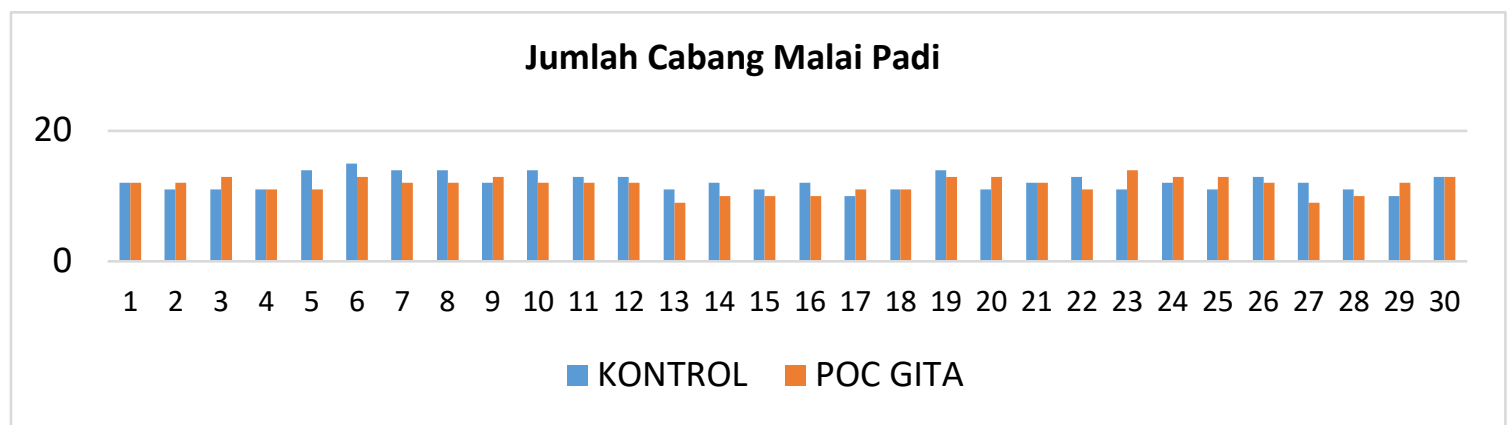

Tabel 4. Tabel Jumlah cabang malai padi, Luwunggede Larangan Brebes 2020

\section{E. Jumlah Bulir Padi Permalai}

Data jumlah bulir padi per malai pada perlakuan kontrol dengan data sebagai berikut data terendah 115 dan tertinggi 189 dengan rerata 144,27 sedangkan pada perlakuan penggunaan POC dengan data terendah mencapai 84 dan tertinggi mencapai angka 218 dengan rerata 153,17 .

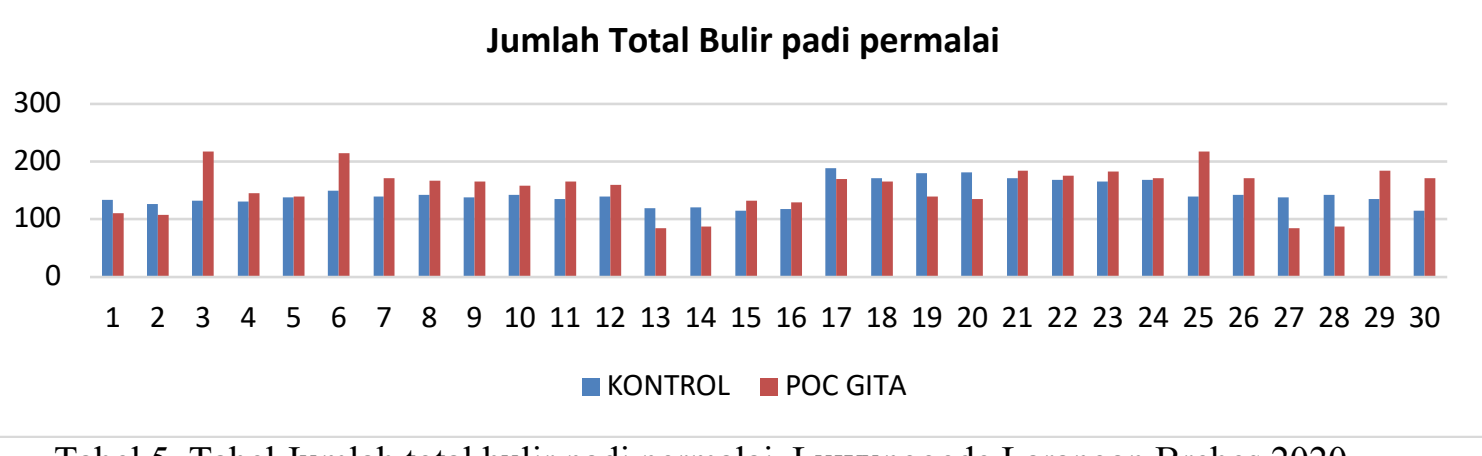

Tabel 5. Tabel Jumlah total bulir padi permalai, Luwunggede Larangan Brebes 2020

\section{F. Bobot Seribu Bulir Padi}

Pada perlakuan kontrol data berat seribu butir padi terendah 26,00 gram dan tertinggi mencapai angka 27,04 gram dengan rerata 26,20 gram, sedangkan pada perlakuan penggunaan POC data terendah 26,89 gram dan tertinggi 27,41 gram dengan rerata 27,12 gram.

\section{Bobot Seribu Bulir Padi}

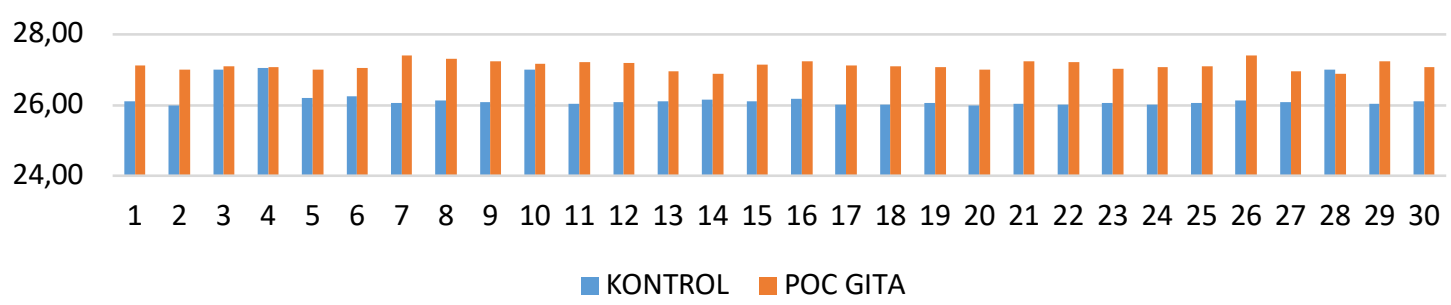

Gambar 6. Grafik Bobot seribu bulir padi, Luwunggede Larangan Brebes 2020 
fisik dan pengukuran dengan alat sederhana uji KTK/Kapasitas Tukar Kation. Kontrol lampu redup POC Nyala Terang. Hasil Soil Test Kit Kontrol, miskin unsur hara makro NPK/ Nitrogen Phosphat dan Kalium sedangkan pada penggunaan POC Hara Makro NPK sangat subur terlihat tebel warna pengukuran Nitrogen lebih Hijau Gelap, Pada Pengukuran Phosphat terlihat Biru lebih tua dan pengukuran Kalium warna Kuning terlihat lebih tua, pengukuran $\mathrm{pH}$ : pada perlakuan Kontrol nilai $\mathrm{pH}$ masuk ketegori Asam, pada penggunaan POC derajad keasaman/pH kategori Normal.

\section{SIMPULAN DAN SARAN}

Dengan pendekatan Key Person dapat mempercepat animo penggunaan Pupuk Organik Cair pada budidaya Padi di desa Luwunggede BPP Brebes Kab Brebes, yang pada akhirnya mampu mengembalikan tingkat kesuburan biologis lahan pertanian sehingga mengembalikan potensi produktivitas lahan pertanian secara nyata.

Harapan penulis yang juga berprofesi sebagai penyuluh pertanian semoga tulisan sederhana ini menginspirasi para pelaku utama dan pelaku usaha untuk ikut andil dan ambil bagian dalam pelestarian lingkungan terlebih dalam mempertahankan dan mengembalikan kesuburan biologis lahan pertanian sehingga mampu menghemat penggunaan pupuk kimia serta meningkatkan potensi hasil pertanian yang pada akhirnya meningkatkan pendapatan dan kesejahteraan petani.

\section{UCAPAN TERIMAKASIH}

Ucapan Syukur Kepada Tuhan Yang Maha Esa dan terima kasih kepada Bupati dan Wakil Bupati Brebes, Kepala Dinas Pertanian dan Ketahanan Pangan, Sekdin DPKP, Para Kabid DPKP dan Kasie DPKP, Koordinator Kelompok Jabatan Fungsional DPKP, Kepala Balai
Penyuluhan Pertanian/BPP Larangan, PPL Sewilayah BPP Larangan, Bpk Ir. H. Slamet. MSi, selaku Key Person pelaku utama sekaligus pelaku usaha pertanian dari desa Luwunggede Kecamatan Larangan, Pihak sponsorship Kompetorindo, Bapak Warsana, Ibu Yohanna F Saatun, Yohanes Caesar, AndreGraf Photography, dan lain lain sehingga penelitian dan penulisan naskah ini dapat terwujud.

\section{PUSTAKA ACUAN}

Anonim. (2015). Monografi BPP Balai Penyuluhan Pertanian Kecamatan Larangan Dinas Pertanian dan Ketahanan Pangan Kabupaten Brebes

Anonim. (2017). Brebes Dalam Angka 2017 Pemerintah Daerah Kabupaten Brebes Provinsi Jawa Tengah.

Anonim. (2018). Programma Penyuluhan Pertanian Balai Penyuluhan Pertanian Larangan Dinas Pertanian dan Ketahanan Pangan Kabupaten Brebes. Anonim. (2019). Impact Point BPP Balai Penyuluhan Pertanian Kecamatan Larangan Kecamatan Brebes Dinas Pertanian dan Ketahanan Pangan Kabupaten Brebes, Provinsi Jawa tengah.

Faiz, M.I. (Agustus 2016). Separuh Lahan Pertanian di Brebes Rusak Akibat Pestisida. Diakses pada https://nasional.tempo.co/read/794853 /separuh-lahan-pertanian-di-brebesrusak-akibat-pestisida.

Hariadi, S.S. (1994). Diktat Kuliah Sosiologi Pedesaan APP Akademi Penyuluhan Pertanian Depertemen Pertanian Yogyakarta

Projosoeharjo. (1987). Dasar Penyuluhan Diktat Kuliah APP Akademi Penyuluhan Pertanian Depertemen Pertanian Yogyakarta.

Savil dalam Moersantoro. (1988). Metode Penyuluhan Diktat Kuliah APP Akademi Penyuluhan Pertanian Depertemen Pertanian Yogyakarta. 
Werimon. (1994). Dasar Komunikasi

Diktat Kuliah Akademi Penyuluhan

Pertanian Depertemen Pertanian

Yogyakarta. 